\title{
PENGARUH KECERDASAN LOGIS MATEMATIS TERHADAP KEMAMPUAN PENALARAN MATEMATIS SISWA SMP NEGERI 23 MUARO JAMBI
}

\author{
Relawati \\ Universitas Batanghari \\ Relawati@unbari.ac.id
}

\begin{abstract}
Abstrak
Penelitian ini dilatarbelakangi oleh rendahnya kemampuan penalaran matematis siswa kelas VIII SMP Negeri 23Muaro Jambi. Adapun tujuan dari penelitian ini adalah untuk mengetahui adakah pengaruh kecerdasan logis matematis terhadap kemampuan penalaran matematis siswa kelas VIII SMP Negeri 23 Muaro Jambi. Pendekatan yang digunakan dalam penelitian ini adalah pendekatan kuantitatif dengan jenis penelitian korelasional. Populasi pada penelitian ini adalah siswa kelas VIII SMP Negeri 23 Muaro Jambi. Pengumpulan data menggunakan tes kecerdasan logis matematis sebanyak 4 item soaldan tes kemampuan penalaran matematis sebanyak 4 item soal. Berdasarkan hasil analisis data, penelitian ini menunjukkanterdapat pengaruh yang positif dan signifikan antara kecerdasan logis matematis terhadap kemampuan penalaran matematis siswa kelas VIII SMPN 23 Muaro Jambi.
\end{abstract}

Kata kunci: kecerdasan logis, kemampuan penalaran matematis.

This research was motivated by the low mathematical reasoning ability of the eighth grade students of SMP Negeri 23 Muaro Jambi. The purpose of this study was to determine whether there is an effect of mathematical logical intelligence on the mathematical reasoning abilities of grade VIII students of SMP Negeri 23 Muaro Jambi. The approach used in this research is a quantitative approach with a correlational research type. The population in this study were students of class VIII SMP Negeri 23 Muaro Jambi. Collecting data using a mathematical logical intelligence test as many as 4 items of questions and a test of mathematical reasoning abilities as many as 4 items. Based on the results of data analysis, this study shows that there is a positive and significant influence between mathematical logical intelligence on the mathematical reasoning abilities of grade VIII students of SMPN 23 Muaro Jambi.

Keywords: logical intelligence, mathematical reasoning ability

\section{PENDAHULUAN}

Matematika merupakan salah satu mata pelajaran yang sangat penting untuk dipelajari oleh setiap siswa di sekolah, dengan mempelajari matematika diharapkan siswa dapat memiliki pola pikir yang inovatif dan imajinatif. NCTM (2000) menyatakan bahwa satu di antara tujuan pembelajaran matematika adalah mengembangkan kemampuan penalaran matematis. Pentingnya kemampuan penalaran bagi siswa sekolah, tertulis dalam Peraturan Menteri Pendidikan Nasional nomor 22 Tahun 2006 tentang standar isi matematika, yaitu agar peserta didik mampu menggunakan penalaran pada pola dan sifat, melakukan manipulasi matematika dalam membuat generalisasi, menyusun bukti, atau menjelaskan gagasan dan pernyataan matematika (Depdiknas, 2006).

Berdasarkan Permendiknas di atas, dapat dilihat bahwa pembelajaran matematika bertujuan untuk mengembangkan segala kemampuan matematis siswa untuk memperoleh hasil belajar matematika yang maksimal. Untuk dapat melakukan proses pembelajaran yang baik, maka harus ditunjang dengan faktor-faktor yang mendukungnya. Adapun faktor yang mendukungnya menurut Slameto (2010), dua diantaranya adalah kecerdasan (inteligensi) dan kesiapan (readiness). Kesiapan adalah keseluruhan kondisi seseorang yang membuatnya siap untuk memberi respon/jawaban di dalam cara 
tertentu terhadap suatu situasi (Slameto, 2010). Kondisi siswa yang telah memiliki kesiapan menerima pelajaran dari guru, akan dapat melakukan kegiatan belajar lebih mudah dan lebih berhasil

Adapun faktor lainnya adalah kecerdasan (inteligensi). Berbicara mengenai factor kecerdasan (inteligensi), maka ada banyak tipe kecerdasan yang dimiliki oleh manusia, salah satunya kecerdasan logis matematis. Menurut Uno \& Umar (Muqowim, 2018) kecerdasan logis matematis adalah kemampuan seseorang dalam berpikir secara induktif dan deduktif, berfikir menurut aturan logika, memahami dan menganalisis pola angka-angka, serta memecahkan masalah dengan menggunakan kemampuan berfikir.

Kecerdasan logis matematis dan kesiapan belajar secara bersama-sama dalam menentukan hasil belajar matematika siswa. Sebagaimana kriteria kecerdasan logis matematis yang menitik beratkan pada kemampuan otak dalam berfikir logis, mengolah angka dan kemampuan berhitung yang apabila dipadukan dengan adanya kesiapan belajar siswa, maka tidaklah mengherankan jika perpaduan keduanya memberikan pengaruh terhadap hasil belajar matematika siswa. Sehingga dapat dikatakan bahwa dengan kemampuan otak berfikir logis dan kecerdasan berhitung inilah yang menjadi modal awal manusia mampu dengan cepat dan tepat memahami pelajaran matematika yang ia terima. Ditambah lagi dengan kesiapan siswa dalam belajar matematika baik itu kesiapan fisik, kesiapan psikis maupun kesiapan materiil, sehingga bias mencapai tahap maksimal.

Berdasarkan hasil observasi peneliti di SMP Negeri 23 Muaro Jambi yaitu siswa masih mengganggap matematika sebagai pelajaran yang sulit, banyak rumus, simbol, perhitungan yang memusingkan. Masalah kedua, masih terdapat beberapa siswa yang tidak mengumpulkan PR dengan alasan yang paling banyak diungkapkan oleh siswa yaitu lupa, beberapa siswa juga tidak mempelajari kembali materi yang di sekolah, dan ada juga siswa yang tidak memiliki buku paket matematika. Masalah ketiga, masih terdapat beberapa siswa yang tidak mempersiapkan dirinya sebelum belajar matematika, seperti sarapan pagi, mempersiapkan alat tulis, dan keperluan lainnya yang berhubungan dengan matematika. Masalah keempat, terdapat beberapa siswa yang kurang aktif pada saat proses pembelajaran berlangsung dan masih terdapat juga beberapa siswa yang enggan bertanya kepada guru apabila belum memahami materi yang sedang berlangsung khususnya materi matematika. Berdasarkan permasalahan-permasalahan tersebut, dapat diindikasikan bahwa kecerdasan logis matematis siswa yang belum berfungsi secara maksimal dan kurangnya kesiapan belajar siswa, sehingga hal inilah yang kemungkinan dapat menyebabkan kemampuan penalaran matematis siswa SMPN 23 Muaro Jambi rendah.

Berdasarkan kamus besar bahasa Indonesia Depdiknas (Maarif, 2015) penalaran berasal dari kata nalar yang artinya sebagai kekuatan pikir.Sedangkan penalaran diartikan sebagai proses mental dalam mengembangkan pikiran dari beberapa fakta atau prinsip. MenurutKeraf (Hendriana dkk, 2017) istilah penalaran secara umum sebagai proses berfikir yang berusaha menghubung-hubungkan faktafakta yang diketahui menuju kepada suatu kesimpulan. Sedangkan menurut Latipah (2017), penalaran merupakan salah satu bentuk dari pengorganisasian pikiran yakni berpikir secara proposisional.

Gardner(Lestari danYudhanegara,2015) mengungkapkan bahwa penalaran matematis adalah kemampuan menganalisis, menggeneralisasi, mensintesis/mengintegrasikan,

memberikan alasan yang tepat dan menyelesaikan masalah tidak rutin. Penjelasan lain tentang penalaran matematis dikemukakan oleh Brodie (Maarif, 2015), yang mengemukakan bahwa penalaran matematis merupakan kemampuan dasar yang dibutuhkan untuk memahami konsep-konsep matematis, menggunakan ide-ide dan prosedur matematika yang fleksibel, serta untuk merekonstruksi pengetahuan matematika yang dipahami.

Secara garis besar terdapat dua jenis penalaran, yaitu : 
1. Penalaran Deduktif

Menurut Suriasumantri (Maarif, 2015:257) penalaran deduktif adalah suatu proses berfikir yang berupa penarikan kesimpulan yang khusus atas dasar pengetahuan tentang hal yang umum (berlaku untuk semua/banyak). Pendapat lain disampaikan oleh Jhonson (Maarif, 2015:257) yang mengatakan bahwa penalaran deduktif adalah proses mental membuat kesimpulan yang logis dari hal yang umum ke hal yang khusus.

2. Penalaran Induktif

Penalaran induktif menurut Artur (Maarif, 2015:257) adalah proses logis dimana terdapat beberapa kejadian yang dipercaya kebenarannya, digabungkan untuk mendapatkan sebuah kesimpulan yang spesifik. Pendapat lain tentang penalaran induktif pun dikemukakan oleh Rhodes (Maarif, 2015:257), yang mengatakan bahwa penalaran induktif merupakan pusat pembelajaran manusia, karena sebagian besar pengetahuan manusia diperoleh dari sebuah kesimpulan induktif daripada melalui pembelajaran langsung atau observasi.

Adapun indikator kemampuan penalaran matematis menurut Sumarmo (Lestari dan Yudhanegara, 2015:82), yaitu:

1. Menarik kesimpulan logis

2. Memberikan penjelasan dengan model, fakta, sifat-sifat, dan hubungan.
3. Memperkirakan jawaban dan proses solusi.

4. Menggunakan pola dan hubungan untuk menganalisis situasi atau membuat analogi dan generalisasi.

5. Menyusun dan menguji konjektur.

6. Membuat counter example (kontra contoh).

7. Mengikuti aturan inferensi dan memeriksa validitas argumen.

8. Menyusun argumen yang valid

9. Menyusun pembuktian langsung, tidak langsung, dan menggunakan induksi matematika.

Sedangkan pada peraturan Dirjen Dikdasmen No.506/C/PP/2004 Depdiknas 2004 (Wardhani, 2008:14), dikatakan bahwa indikator yang menunjukkan penalaran antara lain adalah :

1. Menyajikan pernyataan matematika secara lisan, tertulis, gambar, dan diagram.

2. Mengajukan dugaan (confectures)

3. Melakukan manipulasi matematika

4. Menarik kesimpulan, menyusun bukti, memberikan alasan atau bukti terhadap beberapa solusi

5. Menarik kesimpulan dari pernyataan

6. Memeriksa kesahihan suatu argumen

7. Menemukan pola atau sifat dari gejala matematis untuk membuat generalisasi.

Peneliti hanya menggunakan beberapa indikator tersebut untuk mengukur kemampuan penalaran matematis siswa, karena indikator tersebut sudah dapat menjadi representasi (mewakili) dari keseluruhan indikator penalaran matematis itu sendiri dalam pembuatan tes. Adapun kriteria penskoran yang peneliti gunakan adalah sebagai berikut. 
Tabel 1. Kriteria Penskoran Penalaran Matematis Berdasarkan Indikator

\begin{tabular}{|c|c|c|}
\hline $\begin{array}{l}\text { Indikator Penalaran } \\
\text { Matematis }\end{array}$ & Respon terhadap Masalah & Skor \\
\hline \multirow{5}{*}{$\begin{array}{l}\text { Membuat generalisasi } \\
\text { untuk memperkirakan } \\
\text { jawaban dan proses } \\
\text { penyelesaian }\end{array}$} & Tidak ada jawaban & 0 \\
\hline & $\begin{array}{l}\text { Tidak membuat generalisasi untuk memperkirakan } \\
\text { jawaban dan proses penyelesaian, serta melakukan } \\
\text { perhitungan tetapi salah }\end{array}$ & 1 \\
\hline & $\begin{array}{l}\text { Tidak membuat generalisasi untuk memperkirakan } \\
\text { jawaban dan proses penyelesaian, tetapi melakukan } \\
\text { perhitungan dengan benar }\end{array}$ & 2 \\
\hline & $\begin{array}{l}\text { Membuat generalisasi untuk memperkirakan jawaban } \\
\text { dan proses penyelesaian tetapi salah }\end{array}$ & 3 \\
\hline & $\begin{array}{l}\text { Membuat generalisasi untuk memperkirakan jawaban } \\
\text { dan proses penyelesaian serta melakukan perhitungan } \\
\text { dengan benar dan lengkap }\end{array}$ & 4 \\
\hline \multirow{5}{*}{$\begin{array}{l}\text { Melakukan manipulasi } \\
\text { matematika }\end{array}$} & Tidak ada jawaban & 0 \\
\hline & $\begin{array}{l}\text { Tidak melakukan manipulasi matematika, tetapi } \\
\text { melakukan perhitungan yang salah }\end{array}$ & 1 \\
\hline & $\begin{array}{l}\text { Tidak melakukan manipulasi matematika, tetapi } \\
\text { melakukan perhitungan dengan benar }\end{array}$ & 2 \\
\hline & $\begin{array}{l}\text { Melakukan manipulasi matematika dan melakukan } \\
\text { perhitungan tetapi salah }\end{array}$ & 3 \\
\hline & $\begin{array}{l}\text { Melakukan manipulasi matematika dan melakukan } \\
\text { perhitungan dengan benar dan lengkap }\end{array}$ & 4 \\
\hline \multirow{5}{*}{$\begin{array}{l}\text { Menggunakan pola } \\
\text { dan hubungan untuk } \\
\text { menganalisis situasi } \\
\text { matematika }\end{array}$} & Tidak ada jawaban & 0 \\
\hline & $\begin{array}{l}\text { Tidak menggunakan pola dan hubungan untuk } \\
\text { menganalisis situasi matematika, tetapi melakukan } \\
\text { perhitungan yang salah }\end{array}$ & 1 \\
\hline & $\begin{array}{l}\text { Tidak menggunakan pola dan hubungan untuk } \\
\text { menganalisis situasi matematika, tetapi melakukan } \\
\text { perhitungan dengan benar }\end{array}$ & 2 \\
\hline & $\begin{array}{l}\text { Menggunakan pola dan hubungan untuk menganalisis } \\
\text { situasi matematika dan melakukan perhitungan tetapi } \\
\text { salah }\end{array}$ & 3 \\
\hline & $\begin{array}{l}\text { Menggunakan pola dan hubungan untuk menganalisis } \\
\text { situasi matematika dan melakukan perhitungan dengan } \\
\text { benar dan lengkap }\end{array}$ & 4 \\
\hline \multirow[t]{5}{*}{ Menarik kesimpulan } & Tidak ada jawaban & 0 \\
\hline & $\begin{array}{l}\text { Tidak menarik kesimpulan dan melakukan perhitungan } \\
\text { yang salah }\end{array}$ & 1 \\
\hline & $\begin{array}{l}\text { Tidak menarik kesimpulan, tetapi melakukan } \\
\text { perhitungan dengan benar }\end{array}$ & 2 \\
\hline & $\begin{array}{l}\text { Menarik kesimpulan dan melakukan perhitungan tetapi } \\
\text { salah }\end{array}$ & 3 \\
\hline & $\begin{array}{l}\text { Menarik kesimpulan dan melakukan perhitungan } \\
\text { dengan benar dan lengkap }\end{array}$ & 4 \\
\hline
\end{tabular}

Sumber: modifikasi dari Iqbal (Prosiding Seminar NasionalMatematikadanTerapan, 2016) 
Menurut Gardner (Uno,2009:100), salah satu kecerdasan yang dimiliki oleh manusia adalah kecerdasan logis matematis. Ia mengatakan bahwa kecerdasan logis matematis berkaitan dengan berhitung atau menggunakan angka dalam kehidupan sehari-hari. Sedangkan menurut Iskandar (2009:54) kecerdasan logis matematis adalah kecerdasan yang memuat kemampuan seseorang dalam berfikir secara induktif dan deduktif, kemampuan berfikir menurut aturan logika, memahami dan menganalisa pola angka-angka serta memecahkan masalah dengan menggunakan kemampuan berfikir.

Anak dengan kecerdasan logis matematis yang berkembang dengan baik, menurut Jahja (2011:397) mempunyai ciriciri sebagai berikut:

1. Mampu mengamati objek yang ada di lingkungan

2. Mengenal dan mengerti konsep jumlah, waktu, dan prinsip sebab akibat

3. Mampu dan menunjukkan kemampuan dalam memecahkan masalah yang menuntut pemikiran

4. Mampu mengamati dan mengenali pola dan hubungan.

Adapun indikator kecerdasan logis matematis menurut Musfiroh, (Muqowim, 2018:41-42) sebagai berikut :

1. Dapat menghitung angka di luar kepala dengan mudah dan tepat

2. Menyukai bidang matematika dan ilmu pasti

3. Senang bermain game atau memecahkan teka-teki yang menuntut penalaran dan berpikir logis

4. Senang membuat eksperimen dari pertanyaan

5. Selalu mencari pola, keteraturan, atau logis dalam berbagai hal

6. Tertarik pada perkembanganperkembangan baru di bidang sains

7. Tertarik pada banyak hal yang melibatkan penjelasan rasional

8. Mampu berpikir dengan konsep yang jelas, abstrak, tanpa kata dan gambar

9. Peka terhadap kesalahan penalaran dalam perkataan dan tindakan orang
10.Senang apabila segala sesuatu diukur, dikategorikan, dianalisis, atau dihitung jumlahnya dengan cara tertentu.

Berdasarkan penjelasan di atas, maka dapat disimpulkan bahwa kecerdasan logis matematis adalah kecerdasan yang dimiliki seseorang dalam hal kemampuan berfikir secara induktif dan deduktif, kemampuan berfikir menurut aturan logika, memahami dan menganalisa pola angka-angka serta memecahkan masalah dengan menggunakan kemampuan berfikir. Adapun indikator yang peneliti gunakan adalah sebagai berikut :

1. Mampu memahami masalah

2. Mampu menyusun rencana penyelesaian

3. Memiliki pemahaman operasi matematis

4. Memiliki pemahaman yang baik tentang pola dan hubungan-hubungan

5. Menarik kesimpulan.

\section{METODE}

Berdasarkan permasalahan yang telah dikemukakan sebelumnya, maka Jenis penelitian ini adalah kuantitatif. Menurut Sugiyono (2015:14) penelitian kuantitatif dapat diartikan sebagai metode penelitian yang berlandaskan pada filsafat positivisme, digunakan untuk meneliti pada populasi atau sampel tertentu, teknik pengambilan sampel pada umumnya dilakukan secara random, pengumpulan data menggunakan instrumen penelitian, analisis data bersifat kuantitatif statistik dengan tujuan menguji hipotesis yang telah ditetapkan.

Sesuai dengan permasalahan yang diteliti maka jenis penelitian ini lebih spesifik lagi adalah penelitian korelasi, karena di dalam penelitian ini bertujuan untuk menunjukkan hubungan antara kemampuan penalaran matematis dengan kecerdasan logis siswa kelas VIII SMP Negeri 23 Muaro Jambi. Menurut Sukardi (2013:166) penelitian korelasi adalah suatu penelitian yang melibatkan tindakan pengumpulan data guna menentukan, apakah ada hubungan dan tingkat hubungan antara dua variabel atau lebih.

Menurut Sugiyono (2013:61) populasi adalah wilayah generalisasi yang terdiri atas : objek/subyek yang 
mempunyai kualitas dan karakteristik tertentu yang ditetapkan oleh peneliti untuk dipelajari dan kemudian ditarik kesimpulannya. Berdasarkan teori diatas, maka yang menjadi populasi dalam penelitian ini adalah siswa kelas VIII SMP Negeri 23 Muaro Jambi Tahun Ajaran 2019/2020 yang berjumlah 189 siswa dan terbagi dalam 5 kelas. Sampel (Supangat, 2007:4) adalah bagian dari populasi (contoh), untuk dijadikan sebagai bahan penelaahan dengan harapan contoh yang diambil dari populasi tersebut dapat mewakili (representative) terhadap populasinya. Teknik pengambilan sampel yang digunakan dalam penelitian ini, yaitu random sampling. Maksudnya adalah teknik pengambilan sampel yang memberikan peluang yang sama bagi setiap unsur (anggota) populasi untuk dipilih menjadi anggota sampel. Sampel penelitian ini diambil secara acak (random), karena semua anggota populasi mendapatkan kesempatan yang sama untuk dijadikan sampel. Adapun cara pengambilan sampel yang peneliti gunakan adalah dengan langkah-langkah sebagai berikut:

1. Mengambil nilai kemampuan awal matematika siswa yang diperoleh dari nilai ulangan siswa.

2. Melakukan uji normalitas

3. Melakukan uji homogenitas

4. Uji Kesamaan Rata-rata

5. Teknik Sampling

Sedangkan instrument dalam penelitian ini tes yang digunakan untuk mengukur kecerdasan logis matematis siswa dalam penelitian ini adalah Tes Essay dan tes yang digunakan untuk mengukur kemampuan penalaran matematis siswa dalam penelitian ini adalah Tes Essay..

Hasil instrumen pengumpulan data dalam penelitian yaitu berupa lembar tes kecerdasan logis matematis, dan lembar tes kemampuan penalaran matematis siswa.
Adapun lembar tes kecerdasan logis matematis yang dihasilkan dalam penelitian ini berupa lembar tes uraian yang berisi 4 soal materi bangun datar, sedangkan lembar tes kemampuan penalaran matematis yang dihasilkan dalam penelitian ini berupa lembar tes uraian yang berisi 5 soal materi teorema Pythagoras.

Menurut Hasan (2006:74) menyatakan bahwa regresi linier dapat berupa regresi linier sederhana dan regresi linier berganda. Regresi linier sederhana adalah regresi linier yang hanya melibatkan dua variabel yaitu satu variabel bebas (X) dan satu variabel terikat $(\mathrm{Y})$.

Dalam penelitian ini, peneliti melakukan uji regresi linier sederhana dengan rumus sebagai berikut :

$$
\widehat{Y}=a+b X
$$

Keterangan :

$\mathrm{Y}=$ Kemampuan penalaran matematis siswa

$\mathrm{a}, \mathrm{b}=$ koefisien regresi

$\mathrm{X}=$ Variabel bebas

Uji $F$ bertujuan untuk mengetahui pengaruh variabel independen (variabel bebas) secara bersama-sama terhadap variabel dependen (variabel terikat), apakah pengaruhnya signifikan atau tidak. Adapun rumusnya, sebagai berikut :

$$
\begin{gathered}
F_{\text {hitung }}=\frac{\frac{R^{2}}{K}}{\frac{\left(1-R^{2}\right)}{n-k-1}} \text { (Sugiyono, } \\
2013: 235)
\end{gathered}
$$

Keterangan :

$\mathrm{R}=$ Koefisien Korelasi

$\mathrm{K}$ = banyaknya variabel bebas

$\mathrm{n}=$ jumlah sampel

Kaidahpengujiansignifikansi :

Jika $F_{\text {hitung }} \geq F_{\text {tabel }}$ maka tolak $\mathrm{H}_{\mathrm{O}}$ artinya signifikan dan

Jika $F_{\text {hitung }}<F_{\text {tabel }}$ maka terima $\mathrm{H}_{\mathrm{o}}$ artinya tidak signifikan 


\section{HASIL PENELITIAN DAN PEMBAHASAN}

Berdasarkan uji statistik regresi linier sederhana yang digunakan untuk mengetahui signifikasi pengaruh variabel bebas (kecerdasan logis matematis) secara bersama-sama terhadap variabel terikat (kemampuan penalaran matematis). Adapun dengan menggunakan rumus sebagai berikut :

$$
\begin{gathered}
F_{\text {hitung }}=\frac{\frac{R^{2}}{K}}{\frac{\left(1-R^{2}\right)}{n-k-1}}=10,64 \text { sedangkan } \\
F_{\text {tabel }}=3,09
\end{gathered}
$$

Karena telah diperoleh $F_{\text {hitung }}>F_{\text {tabel }}$ maka Ho ditolak dan $\mathrm{Ha}$ diterima. Jadi koefisien korelasi ganda yang ditemukan adalah signifikan antara kecerdasan logis matematis dan kesiapan belajar terhadap kemampuan penalaran matematis siswa kelas VIII di SMPN 23 Muaro Jambi.

Berdasarkan hasil analisis di atas diperoleh persamaan regresi yaitu $\mathrm{Y}=$ $53,81+0,022 X$. Nilai rata-rata kecerdasan logis-matematis $\left(\mathrm{X}_{1}\right)$ adalah 48,1 . Jika nilai rata-rata kecerdasan logis-matematis dimasukkan dalam persamaan regresi menjadi $\mathrm{Y}=53,81+0,022(48,1)=53,81+$ 1,058 artinya nilai rata-rata kecerdasan logis-matematis sebesar 53,81 poin akan meningkatkan nilai kemampuan penalaran matematis sebesar 1,058 poin. Dan sebaliknya jika nilai kecerdasan logismatematis turun sebesar 53,81 poin maka nilai dari kemampuan penalaran matematis juga mengalami penurunan sebesar 1,058 poin.

Dari hasil analisis di atas, dapat dikemukakan bahwa hipotesis dalam penelitian ini yaitu "terdapat pengaruh kecerdasan logis-matematis terhadap kemampuan penalaran matematis siswa kelas VIII SMPN 23 Muaro Jambi tahun pelajaran 2020/2021" dapat diterima. Adapun pengaruh yang dihasilkan adalah positif dan signifikan. Hal ini terlihat pada korelasi atau nilai $\mathrm{R}=0,39$, menunjukkan derajat hubungan yang lemah, yang berarti bahwa antara variabel kecerdasan logis matematis dan kemampuan penalaran matematis memang terdapat korelasi, akan tetapi korelasi itu lemah.

Jadi ciri-ciri orang yang cerdas secara logis-matematis mencakup kemampuan perhitungan secara matematis, berfikir logis, memecahkan masalah, pertimbangan induktif dan pertimbangan deduktif, ketajaman pola-pola serta dalam hal hubungan-hubungan. Dalam mempelajari, memahami dan memecahan masalah yang berkaitan dengan materi pada mata pelajaran matematika banyak menggunakan kecerdasan ini. Matematika merupakan mata pelajaran yang dirasa sulit bagi sebagian besar siswa, karena dalam materi pada mata pelajaran matematika selain banyak menggunakan angka-angka dan penjelasannya,juga menggunakan penalaran logis. Oleh karena itu, dalam mempelajari, memahami dan memecahkan masalah yang berkaitan dengan mata pelajaran matematika dibutuhkan kecerdasan logismatematis yang tinggi. Jadi apabila siswa memiliki kecerdasan logis matematis dan kesiapan belajar yang tinggi maka kemampuan penalaran matematis siswa tersebut juga tinggi.

\section{SIMPULAN}

Berdasarkan hasil pengolahan data melalui analisis regresi dan korelasi sederhana, serta analisis regresi dan korelasi ganda diperoleh informasi bahwa kecerdasan logis matematis berpengaruh terhadap hasil tes kemampuan penalaran matematis kelass VIII di SMPN 23 Muaro Jambi. Sehingga dapat disimpulkan bahwa terdapat pengaruh antara kecerdasan logis matematis terhadap kemampuan penalaran matematis, hal ini dapat ditunjukkan dengan nilai $r$ sebesar 0,39318. Yang berarti bahwa keeratan hubungan antara kecerdasan logis matematis terhadap kemampuan penalaran matematis siswa tergolong kategori lemah.

\section{REFERENSI}

Depdiknas. (2006). Kurikulum Tingkat SatuanPendidikan (KTSP). Jakarta: DepartemenPendidikanNasional.

Hasan, I. (2006). Analisis Data Penelitian dengan Statistik. Jakarta:PT.Bumi Aksara. 
Hendriana, H. dkk. (2017). Hard Skills dan Soft Skills Matematik Siswa. Bandung : PT. RefikaAditama.

Iskandar. (2009). Psikologi Pendidikan sebuah Orientasi Baru. Ciputat :Gaung Persada (GP) Press.

Jahja, Yudrik. (2011). Psikologi Perkembangan. Jakarta: Kencana Prenada Media Group.

Latipah, Eva. (2017). Psikologi Dasar Bagi Guru.Bandung : PT Remaja Rosdakarya Offset.

Lestari, Karunia, E., Yudhanegara, M.R. (2015). Penelitian Pendidikan Matematika Panduan Praktis Menyusun Skripisi, Tesis, dan Laporan Penelitian dengan Pendekatan Kuantitatif, Kualitatif, dan Kombinasi disertai dengan Model Pembelajaran dan Kemampuan Matematis. Karawang : Refika Aditama.

Maarif, S. (2015). Pembelajaran Geometri Berbantu Cabri 2 Plus (Panduan Praktis Mengembangkan Kemampuan Matematis).Bogor : IN MEDIA.
Muqowim. (2018). Strategi Pembelajaran Anak Usia Dini Berbasis Multiple Intelligences. Jawa Tengah: Penerbit MangkuBumi.

NCTM. (2000). Priciples and Standards for School Mathematic. Reston,VA: NCTM..

Slameto. (2010). Belajar\&Faktor-Faktor yang Mempengaruhi. Jakarta :RinekaCipta.

Sugiyono. (2013). Statistika untuk Penelitian. Bandung : Alfabeta.

Sugiyono. (2015). Metoda Penelitian Pendidikan. Bandung: Alfabeta.

Sukardi.(2013). Metodologi Penelitian Pendidikan Kompetensi dan Ppraktiknya. Jakarta : PT BumiAksara.

Uno, H.B., Kuadrat, M. (2009). Mengelola Kecerdasan dalam Pembelajaran. Jakarta : PT BumiAksara.

Wardhani, S. (2008). Analisis SI dan SKL Mata Pelajaran Matematika SMP/MTs untuk Optimalisasi Pencapaian Tujuan. Yogyakarta: Pusat Pengembangan dan Pemberdayaan Pendidik dan Tenaga Kependidikan Matematika. 